\title{
Poor Knowledge of Tuberculosis among the Population of Jeddah and Makkah Saudi Arabia, a High-Risk Area
}

\author{
Ssakher M. AlOtaibi' ${ }^{1}$, Abdullah F. Almoshadq1, Hosam A. Alghanmi' ${ }^{1}$, Fetoon Aljuiad1, \\ Yasmin R. Soliman', Abdulmajeed T. Alzuair ${ }^{2}$, Osama A. Alzahrani' ${ }^{3}$, \\ Abdulrahman A. Algarni4, Malak Y. Ali ${ }^{5}$
}

${ }^{1}$ King Abdullah Medical City, Makkah, Saudi Arabia

${ }^{2}$ King Abdulaziz University, Jeddah, Saudi Arabia

${ }^{3} J e d d a h$ ' Western Hospital, Jeddah, Saudi Arabia

${ }^{4}$ King Abdulaziz University Hospital, Riyadh, Saudi Arabia

${ }^{5}$ Alnoor Specialist Hospital, Makkah, Saudi Arabia

Email: dr.sakher10@gmail.com

How to cite this paper: AlOtaibi, S.M., Almoshadq, A.F., Alghanmi, H.A., Aljuiad, F., Soliman, Y.R., Alzuair, A.T., Alzahrani, O.A., Algarni, A.A. and Ali, M.Y. (2016) Poor Knowledge of Tuberculosis among the Population of Jeddah and Makkah Saudi Arabia, a High-Risk Area. Journal of Tuberculosis Research, 4, 81-91.

http://dx.doi.org/10.4236/jtr.2016.43010

Received: May 30, 2016

Accepted: August 6, 2016

Published: August 9, 2016

Copyright $\odot 2016$ by authors and Scientific Research Publishing Inc. This work is licensed under the Creative Commons Attribution International License (CC BY 4.0).

http://creativecommons.org/licenses/by/4.0/ (c) (†)

Open Access

\begin{abstract}
SETTING: Millions of pilgrims visit Makkah (Mecca), Saudi Arabia, from regions of endemic tuberculosis. Little consideration has been given to the potential impact of this disease on the local population. OBJECTIVES: To assess knowledge about TB among residents of Makkah and Jeddah (Makkah's principal travel gateway). METHODS: A cross-sectional survey of 1004 residents. Data were analyzed by gender. RESULTS: Spread of TB by coughing was a transmission route known by $44.2 \%$ of males and $59.6 \%$ of females $(\mathrm{P}<0.001) ; 20.0 \%$ of participants knew that TB is caused by bacteria; $71.6 \%$ of females and $52.3 \%$ of males knew $\mathrm{TB}$ is infectious $(\mathrm{P}<$ 0.001 ). Regarding approaches to TB prevention, $48.0 \%$ of respondents answered patient isolation and $15.2 \%$ vaccination. Overall, $50.6 \%$ of males and $38.3 \%$ of females $(\mathrm{P}<0.001)$ would seek modern medical treatment if hemoptysis occurred. With a persistent cough, $65.4 \%$ of respondents would do nothing or wait before consulting a healthcare provider. High numbers of "don't know" responses were recorded throughout the survey. CONCLUSIONS: Within the population across pilgrimage areas in Saudi Arabia, knowledge is lacking concerning TB transmission, the cause of the disease, means of prevention and the success of treatment, highlighting an urge need for better public education.
\end{abstract}

\section{Keywords}

Awareness, Hajj, International Travel, Multi-Drug Resistance, Pilgrimage 


\section{Introduction}

Saudi Arabia (KSA) hosts the annual Hajj pilgrimage to Makkah (Mecca), the holiest city of Islam. More than 3 million people come from over 180 countries to participate during the $12^{\text {th }}$ month of the Islamic calendar. Hajj is one of the Five Pillars of Islam and must be undertaken by all able-bodied adult Muslims who can afford it. Several million more pilgrims participate in Umrah, another pilgrimage to Makkah that can be undertaken at any time of the year. Jeddah is the second largest city in KSA and the principal international travel gateway to Makkah.

Millions of pilgrims each year come from outside KSA [1], and over 50\% from regions where tuberculosis is endemic, such as India, Pakistan, Bangladesh, southeast Asia and Africa. Asia and Africa account for $85 \%$ of global TB cases [2]. The Hajj represents a major infection challenge with few global equivalents. Pilgrims are mostly middle-aged and elderly, conditions during Hajj are overcrowded and hot, participants undertake exhausting rituals, suffer sleep deprivation and poor nutrition, and often already suffer from illnesses [3]. Studies have reported that $>50 \%$ of Hajj participants suffer from coughs [4], and upper respiratory tract infections are the most common disease during the Hajj [5]. These factors are highly conducive to the spread of TB. In one study, a TB immune response was found 3 months after returning home in $10 \%$ of pilgrims who had tested negative before attending the Hajj [6]. The risk of spread of TB among pilgrims has been well-documented [1] [2] [5] [7]. However, far less consideration has been given to the potential disease impact on the local resident population.

The overall TB incidence rate in KSA is approximately $16 / 100,000$ and the death rate is approximately 1000 per annum; the incidence among Saudi nationals is $12 / 100,000$ compared to $25 / 100,000$ among non-nationals [3]-[8]. BCG vaccination is compulsory at birth in KSA, and TB treatment is free in government hospitals. However, the western region including Makkah and Jeddah has an incidence of $24 / 100,000$, which is well above the national average and is rising rapidly, in contrast to the pattern elsewhere across KSA [2] [3]. Other reports put the incidence in this region as high as 64/100,000 [9]. The tuberculin sensitivity test (TST) rate in the Western province of KSA has been reported as $20 \%$ [10]. There is obvious potential for TB transmission from pilgrims to the local population with whom they are in frequent contact. Some non-Saudi pilgrims remain in the Makkah region for work, but tend to have poor healthcare and housing because of fear of deportation; it is considered likely that they contribute to the high incidence of TB in this region [2]. Furthermore, studies have highlighted significant positive TST rates among healthcare workers in KSA, which represents another potential route of transmission [11]. These considerations mean it is crucial to assess awareness and knowledge of TB in the population of Makkah and Jeddah.

In this work, we surveyed residents of these cities to assess their knowledge about the causes and infectivity of TB, and the prevention and treatment of the disease. Few previous studies have assessed awareness of TB among Saudi populations, but research into students at King Saud University, Riyadh, and in the general population of Jeddah has revealed that knowledge was poor even among well-educated people [9]-[12]. Our 
aim was to highlight any deficiencies in knowledge in the populations of Makkah and Jeddah to help improve awareness efforts.

\section{Methodology}

\subsection{Ethics}

The Ethics Committee of King Abdullah Medical City approved this study. The purpose of the study was explained to all participants and their informed consent was obtained. Surveys were conducted anonymously in writing and participants were assured of the confidentiality of their responses. Anyone was free to decline to participate in the survey.

\subsection{Study Design and Population}

A cross-sectional study was conducted among 1004 residents of Jeddah and Makkah, KSA, in which our questionnaire was distributed randomly at the entries of all the malls in Jeddah and Makkah. The response rate to the survey was $51 \%$. The questionnaire was adapted from resources [13] [14] that meet the world health organization standards, translated into Arabic by an infectious disease control consultant, and retranslated by a native Arabic speaker; the English versions were compared and found to avoid mismatches, this questionnaire was modified to meet our environment needs, background and limitations.

\subsection{Statistical Analysis}

Gender differences in demographic characteristics and knowledge of TB transmission, symptoms, prevention and treatment factors were analyzed using a chi-square test or a Fisher's exact test for small numbers as appropriate. For all analyses, P-values $<0.05$ were considered significant. All analyses were conducted in Stata version 14 (StataCorp, College Station, Texas).

\section{Results}

We surveyed 1004 residents of the cities of Makkah and Jeddah, Saudi Arabia, a region where the population are at relatively high risk of exposure to TB because it is a center of large-scale, global pilgrimage. The respondents were divided by gender ( male $=419$, female $=585$ ). Table 1 shows summary demographic information concerning the survey participants. Table 2 shows responses to questions on the spread of TB, and knowledge about the cause, infectivity and preventability of the disease. Table 3 reports answers to questions on treatment of TB and individual responses to symptoms.

The spread of TB by coughing or aerosol was recognized as a transmission route by $44.2 \%$ of males and $59.6 \%$ of females $(\mathrm{P}<0.001$ between the gender groups) who responded to our questions (Table 2). A substantial proportion of respondents said they did not know the route of transmission (22.3\%), and many gave incorrect answers. Only $20.0 \%$ of our participants (201/1004) knew that TB is caused by bacteria; $38.1 \%$ thought the disease is viral and $38.6 \%$ did not know (Table 2). Around two-thirds knew 
Table 1. Summary demographic characteristics of survey participants.

\begin{tabular}{lccc}
\hline \multicolumn{1}{c}{ Characteristic } & $\begin{array}{c}\text { Male } \\
(\mathrm{n}(\% \text { of males }))\end{array}$ & $\begin{array}{c}\text { Female } \\
(\mathrm{n}(\% \text { of females }))\end{array}$ & $\begin{array}{c}\text { Total } \\
(\mathrm{n} \text { (\% of total) }\end{array}$ \\
\hline Gender & 419 & 585 & 1004 \\
Age (years) & & & \\
$10-19$ & $198(47.2)$ & $270(46.2)$ & $468(46.6)$ \\
$20-29$ & $97(23.1)$ & $94(16.1)$ & $191(19.0)$ \\
$30-39$ & $68(16.2)$ & $117(20.0)$ & $185(18.4)$ \\
$40-49$ & $37(8.8)$ & $73(12.5)$ & $110(11.0)$ \\
$50-59$ & $18(4.3)$ & $20(3.4)$ & $38(3.8)$ \\
$\geq 60$ & $1(0.2)$ & $11(1.9)$ & $12(1.2)$
\end{tabular}

Level of education

None

Primary

Intermediate

Secondary

University

Higher

City of residence

Jeddah

Makkah

Nationality

$$
\text { Saudi }
$$

Non-Saudi

Have you ever been infected with TB?

Yes
No

Do you know someone who has been infected with $\mathrm{TB}$ ?

Yes

$67(16.0)$

$119(20.3)$

$466(79.7)$
$19(1.9)$

$46(4.6)$

$237(23.6)$

$380(37.8)$

$305(30.4)$

$17(1.7)$

$157(37.5)$

$249(42.6)$

406 (40.4)

$262(62.5)$

$336(57.4)$

598 (59.6)

$324(77.3)$

$466(79.7)$

790 (78.7)

95 (22.7)

$119(20.3)$

$214(21.3)$

$9(2.1)$

$9(1.5)$

$18(1.8)$

410 (97.9)

$576(98.5)$

986 (98.2) 
Table 2. Disease characteristics of TB.

\begin{tabular}{|c|c|c|c|}
\hline Question and response & $\begin{array}{c}\text { Male } \\
\text { (n (\% of males)) }\end{array}$ & $\begin{array}{c}\text { Female } \\
(\mathrm{n}(\% \text { of females }))\end{array}$ & $\begin{array}{c}\text { Total } \\
(\mathrm{n}(\% \text { of total }))\end{array}$ \\
\hline Gender & 419 & 585 & 1004 \\
\hline \multicolumn{4}{|l|}{ How is TB spread? } \\
\hline Cough (air) & $185(44.2)$ & $349(59.7)$ & $534(53.2)$ \\
\hline Unclean food/water & $42(10.0)$ & $46(7.9)$ & $88(8.8)$ \\
\hline Public area & $47(11.2)$ & $42(7.2)$ & $89(8.9)$ \\
\hline Sexual contact with TB patient & $34(8.1)$ & $22(3.8)$ & $56(5.6)$ \\
\hline Hereditary & $4(1.0)$ & $9(1.5)$ & $13(1.3)$ \\
\hline Don't know & $107(25.5)$ & $117(20.0)$ & $224(22.3)$ \\
\hline \multicolumn{4}{|l|}{ What is the cause of TB? } \\
\hline Bacteria & $76(18.1)$ & $125(21.4)$ & $201(20.0)$ \\
\hline Virus & $140(33.4)$ & $243(41.5)$ & $383(38.1)$ \\
\hline Fungus & $19(4.5)$ & $13(2.2)$ & $32(3.2)$ \\
\hline Don't know & $184(44.2)$ & $204(34.9)$ & $388(38.6)$ \\
\hline \multicolumn{4}{|l|}{ Is TB infectious? } \\
\hline Yes & $219(52.3)$ & $419(71.6)$ & $638(63.5)$ \\
\hline No & $31(7.4)$ & $40(6.8)$ & $71(7.1)$ \\
\hline Don't know & $169(40.3)$ & $126(21.5)$ & $295(29.4)$ \\
\hline \multicolumn{4}{|l|}{ Is TB preventable? } \\
\hline Yes & $269(64.2)$ & $439(75.0)$ & $708(70.5)$ \\
\hline No & $44(10.5)$ & $16(2.7)$ & $60(6.0)$ \\
\hline Don’t know & $106(25.3)$ & $130(22.2)$ & $236(23.5)$ \\
\hline \multicolumn{4}{|l|}{ How is TB preventable? } \\
\hline Patient isolation & $195(46.5)$ & $287(49.1)$ & $482(48.0)$ \\
\hline Avoid exposure to mosquitos & $28(6.7)$ & $22(3.8)$ & $50(5.0)$ \\
\hline Cannot prevent it & $12(2.9)$ & $7(1.2)$ & $19(1.9)$ \\
\hline Not eating uncovered food & $12(2.9)$ & $14(2.4)$ & $26(2.6)$ \\
\hline Wash your hands with soap & $30(7.2)$ & $34(5.8)$ & $64(6.4)$ \\
\hline Vaccination & 49 (11.7) & $104(17.8)$ & $153(15.2)$ \\
\hline Don't know & $93(22.2)$ & $117(20.0)$ & $210(20.9)$ \\
\hline
\end{tabular}


Table 3. Treatment of TB and response to symptoms.

\begin{tabular}{|c|c|c|c|}
\hline Question and response & $\begin{array}{c}\text { Male } \\
\text { (n (\% of males)) }\end{array}$ & $\begin{array}{c}\text { Female } \\
(\mathrm{n}(\% \text { of females }))\end{array}$ & $\begin{array}{c}\text { Total } \\
(\mathrm{n}(\% \text { of total }))\end{array}$ \\
\hline Gender & 419 & 585 & 1004 \\
\hline \multicolumn{4}{|l|}{ Is $\mathrm{TB}$ treatable? } \\
\hline Yes & $265(63.2)$ & $397(67.9)$ & $662(65.9)$ \\
\hline No & $43(10.3)$ & $40(6.8)$ & $83(8.3)$ \\
\hline Don't know & $111(26.5)$ & $148(25.3)$ & $259(25.8)$ \\
\hline \multicolumn{4}{|l|}{ Is complete recovery possible? } \\
\hline Yes & $100(23.9)$ & $180(30.8)$ & $280(27.9)$ \\
\hline No & $45(10.7)$ & $90(15.4)$ & $135(13.4)$ \\
\hline Don’t know & $274(65.4)$ & $315(53.8)$ & $589(58.7)$ \\
\hline \multicolumn{4}{|l|}{$\begin{array}{l}\text { If you had a cough with blood, what } \\
\text { would you do? }\end{array}$} \\
\hline Self-treatment & $14(3.3)$ & $26(4.4)$ & $40(4.0)$ \\
\hline Traditional medicine & $182(43.4)$ & $326(55.7)$ & $508(50.6)$ \\
\hline Modern medicine & $212(50.6)$ & $224(38.3)$ & $436(43.4)$ \\
\hline Consult someone & $11(2.6)$ & $9(1.5)$ & $20(2.0)$ \\
\hline \multicolumn{4}{|l|}{$\begin{array}{l}\text { If you had a persistent cough with no } \\
\text { blood, what would you do? }\end{array}$} \\
\hline Nothing & $71(16.9)$ & $85(14.5)$ & $156(15.5)$ \\
\hline Self-treatment & $20(4.8)$ & $13(2.2)$ & $33(3.3)$ \\
\hline Ask a family member or friend & $137(32.7)$ & $177(30.3)$ & $314(31.3)$ \\
\hline $\begin{array}{l}\text { Wait before consulting a } \\
\text { healthcare provider }\end{array}$ & $191(45.6)$ & $310(53.0)$ & $501(49.9)$ \\
\hline
\end{tabular}

that TB is infectious (71.6\% of females, $52.3 \%$ of males, $\mathrm{P}<0.001)$, and $70.5 \%$ considered it preventable, with a significantly higher proportion of females than males knowing about preventability $(\mathrm{P}<0.001)$. Participants were asked about the best method of preventing TB in a question that allowed a free choice of answer: $48.0 \%$ responded patient isolation and $15.2 \%$ answered vaccination (Table 2 ); females indicated vaccination in higher proportion than males, with a significant difference between genders $(\mathrm{P}=$ 0.008). Around two-thirds of respondents knew that TB is treatable (females signifi- 
cantly more than males, $\mathrm{P}=0.040$ ), but $58.7 \%$ did not know whether complete recovery is possible (no significant difference by gender) (Table 3 ). Only $50.6 \%$ of males and $38.3 \%$ of females $(\mathrm{P}<0.001)$ would seek modern medical treatment if suffering from a cough with blood; females were considerably more likely than males ( $55.7 \%$ vs $43.4 \%, \mathrm{P}$ $<0.001$ ) to use traditional medicine (Table 3). If suffering a persistent cough (without blood), $15.5 \%$ of respondents would do nothing, while $45.6 \%$ of males and $53.0 \%$ of females ( $\mathrm{P}=0.031)$ would wait for some time before consulting a healthcare provider (Table 3). A pattern of a high proportion of “don't know" responses was observed throughout our survey (Table 2 and Table 3 ).

\section{Discussion}

Knowledge of $\mathrm{TB}$ is significantly associated with positive healthcare-seeking action [15], increased compliance with treatment regimens and a higher cure rate [16]. TB control can be enhanced by improvement in knowledge and attitudes towards the disease [17]. Public awareness correlates with early detection of TB [12]. Meanwhile, baseline studies are important to highlight present deficiencies in knowledge and to track the progress of any public health education or policy measures taken in the future. Our results indicate a worrying lack of knowledge among the sampled population in Jeddah and Makkah.

\subsection{A Need for Greater Awareness and Education about TB}

We observed poor levels of knowledge of TB concerning the means of transmission, the cause of the disease, means of prevention and the success of treatment. Less than half of those surveyed would seek modern medical help if suffering from hemoptysis. These findings highlight an urgent need for extensive public education about TB in western Saudi Arabia. Our results are perhaps surprising as $69.9 \%$ of our interviewees were educated to secondary level or above. Al-Orainey advocated the need for public education regarding TB symptoms and treatment in the Hajj region, combined with annual screening of those in frequent contact with pilgrims and disease surveillance of the local population [3]. Our findings support the necessity for such measures.

\subsection{Comparison with Previous Surveys of TB Knowledge and Awareness in KSA}

Samargandi et al. surveyed the population of Jeddah about pulmonary TB in 2010, and AlSalem et al. surveyed university students in Riyadh about TB awareness in work published in 2015 [9]-[12]. Samargandi and colleagues found that $49 \%$ of respondents knew TB was an infectious disease compared with around $63 \%$ overall in our work and that of AlSalem. However, in the Jeddah and university surveys, $49 \%$ and $43.4 \%$ respectively knew that TB is bacterial in origin, compared with the strikingly low value reported in this current study (20.0\%). Similar proportions in the three studies $(53 \%$ $66 \%)$ knew that TB is transmitted by an airborne route. In huge contrast to our results, AlSalem et al. reported that $79.7 \%$ considered TB is prevented primarily by vaccination, 
compared with only $15.2 \%$ in this report. All three studies highlight major deficiencies in overall knowledge about TB. Our study and that of Samargandi et al. indicate somewhat better knowledge among females than males, but there was no significant difference in gender-specific awareness in the student survey. The large discrepancies in certain findings between these three studies indicate that further research may be worthwhile.

\subsection{Implications of Our Findings}

Late diagnosis and treatment is a major problem in TB control as it facilitates the spread of the disease [2]. Therefore, our results relating to individuals' response to symptoms may be particularly troubling-i.e., many would seek help from traditional rather than modern medicine practitioners, and many would do nothing or wait before seeking any medical help at all. Although we did not address the question directly, our results hint at a stigma associated with TB among the survey population. This was reflected both in the high level of respondents $(48.0 \%)$ who considered patient isolation to be the most effective means of TB prevention, and the proportion (around 65\%) who delay seeking medical help, or not seek help, if suffering a persistent cough. The possibility of stigma revealed by our research again highlights the need for better TB education, and also indicates that research into the stigmatization of individuals with TB would be appropriate in KSA.

Another important consideration is the potential of the large-scale international pilgrimage to Makkah to spread drug-resistant TB [7]. A significant and increasing proportion of TB isolates are multi- or extensively-drug-resistant. Hajj and Umrah represent occasions on which drug-resistant strains can be introduced to residents of KSA, and by which strains can be spread globally when pilgrims mix and then return home. Highlevel misuse of antibiotics and low levels of knowledge about effective antibiotic use have been highlighted in Saudi Arabia [18], as has large scale non-compliance with TB treatment regimens [19], all of which contribute to drug resistance. Reports indicate a higher level of drug-resistant TB in the Makkah and Madinah (another city of pilgrimage) regions of Saudi Arabia than elsewhere in the country [7] [20] [21]. These observations again indicate the need for education on TB treatment, and also on effective therapeutic drug use for residents of the pilgrimage regions of KSA.

Some TB awareness campaigns are already underway in this region, particularly the Jeddah “Stop TB" group. Their activities, coordinated with the World Health Organization and the Saudi Ministry of Health, include mobilization of medical volunteers, awareness campaigns in shopping malls, restaurants and cafes, traditional media activities, internet and social media campaigns, and a 30,000-participant youth march for patients with TB [22]-[24]. Academic studies have highlighted the value of television in spreading TB awareness, for example in northeast Libya, Tehran, Pakistan and among Saudi university students [12] [25]-[27]. A previous Saudi study concluded that public education including media-based public health campaigns was the best way to increase disease awareness [9]. Broad-based media and internet/social media approaches should 
be considered for TB education in the Jeddah-Makkah region.

\subsection{Limitations of This Study}

This was a cross-sectional study with all of the inherent limitations that implies; for example, difficulties in drawing causal inferences, the "snapshot" nature of the study and problems in generating representative samples. Of note is that the male and female groups were not age-matched; in particular, where data are limited to people aged $<30$ years, males tended to be older, while females tended to be older when considering the highest age groups in this survey. Moreover, among the whole survey, around 50\% of interviewees were $\leq 19$ years old and few were over $\geq 50$ years. Such factors could influence the survey outcomes, particularly with regards to questions related to experience, and therefore confound effects either observed or not observed in the analysis. The comparisons in this work were unadjusted (univariate) and thus did not control for the influence of confounders or systematic differences between males and females, which may have influenced how they would respond to the questions.

\section{Conclusion}

This study provides a basis for discussions of public policy towards TB awareness and education in Saudi Arabia, especially in the west of the country which has a higher incidence of the disease and is a site of major pilgrimage for millions of visitors each year from countries where TB is endemic. Development of an evidence base for intervention into TB transmission is a priority for the KSA Ministry of Health [1]. Significant and urgent public education is required about the cause and treatment of TB. While extensive processes address the medical needs of visiting Hajj pilgrims, sufficient consideration must also be given to the health and awareness of the local population.

\section{References}

[1] Memish, Z.A., Zumla, A., Alhakeem, R.F., et al. (2014) Hajj: Infectious Disease Surveillance and Control. The Lancet, 383, 2073-2082. http://dx.doi.org/10.1016/S0140-6736(14)60381-0

[2] Al-Orainey, I., Alhedaithy, M.A., Alanazi, A.R., Barry, M.A. and Almajid, F.M. (2013) Tuberculosis Incidence Trends in Saudi Arabia over 20 Years: 1991-2010. Annals of Thoracic Medicine, 8, 148-152. http://dx.doi.org/10.4103/1817-1737.114303

[3] Al-Orainey, I.O. (2013) Tuberculosis Infection during Hajj Pilgrimage. The Risk to Pilgrims and Their Communities. Saudi Medical Journal, 34, 676-680.

[4] Alzeer, A.H. (2009) Respiratory Tract Infection during Hajj. Annals of Thoracic Medicine, 4, 50-53. http://dx.doi.org/10.4103/1817-1737.49412

[5] Al-Tawfiq, J.A. and Memish, Z.A. (2012) The Hajj: Updated Health Hazards and Current Recommendations for 2012. Euro Surveillance, 17, 20295.

[6] Wilder-Smith, A., Foo, W., Earnest, A. and Paton, N.I. (2005) High Risk of Mycobacterium tuberculosis Infection during the Hajj Pilgrimage. Tropical Medicine \& International Health, 10, 336-339. http://dx.doi.org/10.1111/j.1365-3156.2005.01395.x

[7] Al-Tawfiq, J.A. and Memish, Z.A. (2015) Potential Risk for Drug Resistance Globalization at the Hajj. Clinical Microbiology and Infection, 21, 109-114. http://dx.doi.org/10.1016/j.cmi.2014.11.013 
[8] Al-Hajoj, S.A. (2010) Tuberculosis in Saudi Arabia: Can We Change the Way We Deal with the Disease? Journal of Infection and Public Health, 3, 17-24.

http://dx.doi.org/10.1016/j.jiph.2009.12.001

[9] Samargandi, O.A., Abulaban, A.A., El Deek, B.S., Mirdad, H. and Wali, S.O. (2012) Knowledge of Pulmonary Tuberculosis in the Saudi Community in Jeddah. Saudi Journal of Internal Medicine, 2, 29-34.

[10] Al-Kassimi, F.A., Abdullah, A.K., Al-Hajjaj, M.S., Al-Orainey, I.O., Bamgboye, E.A. and Chowdhury, M.N.H. (1993) Nationwide Community Survey of Tuberculosis Epidemiology in Saudi Arabia. Tubercle and Lung Disease 74, 254-260. http://dx.doi.org/10.1016/0962-8479(93)90051-X

[11] Abbas, M.A.F., AlHamdan, N.A.E., Fiala, L.A., AlEnezy, A.K. and AlQahtani, M.S. (2010) Prevalence of Latent TB among Health Care Workers in four Major Tertiary Care Hospitals in Riyadh, Saudi Arabia. The Journal of the Egyptian Public Health Association, 85, 61-71.

[12] AlSalem, S.B., AlEisa, A.M., Raslan, I.A. and Binjawhar, A.S. (2015) Tuberculosis: Awareness among Students in a Saudi University. Health, 7, 175-182.

http://dx.doi.org/10.4236/health.2015.72020

[13] Abebe, G., Deribew, A., Apers, L., Woldemichael, K., Shiffa, J., et al. (2010) Knowledge, Health Seeking Behavior and Perceived Stigma towards Tuberculosis among Tuberculosis Suspects in a Rural Community in Southwest Ethiopia. PLoS ONE, 5, e13339. http://dx.doi.org/10.1371/journal.pone.0013339

[14] Liefooghe, R., Baliddawa, J.B., Kiruto, E.M., Vermeire, C. and De Munynck, A.O. (1997) From Their Own Perspective. A Kenyan Community's Perception of Tuberculosis. Tropical Medicine and International Health, 2, 809-821.

[15] Hoa, N.P., Thorson, A.E.K., Long, N.H. and Diwan, V.K. (2003) Knowledge of Tuberculosis and Associated Health-Seeking Behaviour among Rural Vietnamese Adults with a Cough for at Least Three Weeks. Scandinavian Journal of Public Health, 31, 59-65. http://dx.doi.org/10.1080/14034950310015121

[16] Morsy, A.M., Zaher, H.H., Hassan, M.H. and Shouman, A. (2003) Predictors of treatment failure among tuberculosis patients under DOTS strategy in Egypt. Eastern Mediterranean Health Journal, 9, 689-701.

[17] Alvarez-Gordillo, G.D.C., Alvarez-Gordillo, J.F., Dorantes-Jiménez, J.E. and Halperin-Frisch, D. (2000) Percepciones y prácticas relacionadas con la tuberculosis y la adherencia al tratamiento en Chiapas, México. Salud Pública de México, 42, 520-528.

http://dx.doi.org/10.1590/S0036-36342000000600008

[18] Belkina, T., Al Warafi, A., Eltom, E.H., Tadjieva, N., Kubena, A. and Vicek, J. (2014) Antibiotic Use and Knowledge in the Community of Yemen, Saudi Arabia, and Uzbekistan. Journal of Infection in Developing Countries, 8, 424-429. http://dx.doi.org/10.3855/jidc.3866

[19] Al-Hajjaj, M.S. and Al-Khatim, I.M. (2000) High Rate of Non-Compliance with AntiTuberculosis Treatment despite a Retrieval System: A Call for Implementation of Directly Observed Therapy in Saudi Arabia. The International Journal of Tuberculosis and Lung Disease, 4, 345-349.

[20] Yezli, S. and Memish, Z.A. (2012) Tuberculosis in Saudi Arabia: Prevalence and Antimicrobial Resistance. Journal of Chemotherapy, 24, 1-5. http://dx.doi.org/10.1179/1120009X12Z.0000000001

[21] Al-Hajoj, S., Varghese, B., Shoukri, M.M., et al. (2013) Epidemiology of Antituberculosis Drug Resistance in Saudi Arabia: Findings of the First National Survey. Antimicrobial Agents and Chemotherapy, 57, 2161-2166. http://dx.doi.org/10.1128/AAC.02403-12 
[22] Arab News, 29 March 2013. Jeddah’s “Stop TB” Group Joins World Tuberculosis Day. http://www.arabnews.com/news/446406

[23] Stop TB Partnership. Sharing of experiences: Italy and Saudi Arabia. http://www.stoptb.org/assets/documents/countries/partnerships/Sharing\%20of\%20Experien ces final.pdf

[24] Stop TB Partnership. Regional \& National Partnerships to Stop TB in the Eastern Mediterranean Region.

http://www.stoptb.org/assets/documents/countries/partnerships/Partnership\%20in\%20EM $\underline{\text { R.pdf }}$

[25] Solliman, M.A., Hassali, M.A., Al-Haddad, M., et al. (2012) Assessment of Knowledge towards Tuberculosis among General Population in North East Libya. Journal of Applied Pharmaceutical Science, 2, 24-30. http://dx.doi.org/10.7324/JAPS.2012.2420

[26] Hadi, M.A.E., Jalilvand, M. and Hadian, M. (2006) Assessment of the Amount of Knowledge and Attitude of Tehran High School Students Regarding Tuberculosis. Tanaffos, 5, 23-28.

[27] Mushtaq, M.U., Majrooh, M.A., Ahmad, W., et al. (2010) Knowledge, Attitudes and Practices Regarding Tuberculosis in Two Districts of Punjab, Pakistan. The International Journal of Tuberculosis and Lung Disease, 14, 303-310.

Submit or recommend next manuscript to SCIRP and we will provide best service for you:

Accepting pre-submission inquiries through Email, Facebook, LinkedIn, Twitter, etc. A wide selection of journals (inclusive of 9 subjects, more than 200 journals)

Providing 24-hour high-quality service

User-friendly online submission system

Fair and swift peer-review system

Efficient typesetting and proofreading procedure

Display of the result of downloads and visits, as well as the number of cited articles

Maximum dissemination of your research work

Submit your manuscript at: http://papersubmission.scirp.org/ 